\title{
Seasonal trend in burrow depth and tidal variation in feeding activity of Nereis diversicolor
}

\author{
Peter Esselink ${ }^{1,2}$, Leo Zwarts ${ }^{3}$ \\ ${ }^{1}$ Zoological Laboratory, University of Groningen, PO Box 14, 9750 AA Haren, The Netherlands \\ ${ }^{2}$ Rijkswaterstaat, Tidal Waters Division, PO Box 207, 9750 AE Haren, The Netherlands \\ ${ }^{3}$ Rijkswaterstaat Flevoland, PO Box 600, 8200 AP Lelystad, The Netherlands
}

\begin{abstract}
Ragworms Nereis diversicolor live in burrows which, if deeper than 5 to $10 \mathrm{~cm}$, offer a safe refuge from most of their predators. Burrow depth must be $c$ a $15 \mathrm{~cm}$ before they live out of reach of all predators. Burrow depth increases with body size, levelling off at $\mathrm{ca} 15 \mathrm{~cm}$, when the depth refuge is reached. Worms live at greater depths in sand than in mud, but this effect disappears if worms with identical body condition (expressed as deviation from mean body weight for a given body length) are compared. Seasonal variation in burrow depth is correlated with sea temperature and to a lesser extent with day length and body condition. Feeding worms are present near or at the surface. Filter feeding occurs in the first $2 \mathrm{~h}$ after exposure (at least if a water film still remains at the surface) and surface feeding begins after that. The total time spent at the surface does not exceed an average of $50 \mathrm{~s}$ per tidal cycle. Feeding must be an extremely risky activity, because predators readily catch most $N$ diversicolor while present near or at the surface.
\end{abstract}

\section{INTRODUCTION}

Although the estuarine polychaete Nereis diversicolor (O. F. Müller) lives in semi-permanent burrows which provide refuge from predators, they are nevertheless eaten by many predators, particularly wading birds (Zwarts \& Esselink 1989 [companion article]). The deeper the burrow, the lower the predation risk, since most predators move over the surface and have to dig or probe in the substrate to find a worm. Predation pressure by other benthic animals seems to be low. The distribution of $N$. diversicolor barely overlaps those of 2 potential benthic predators, Nereis virens and Nephtys hombergii (Wolff 1973, Kristensen 1984, Zwarts 1988), and moreover the latter species is only able to take the smallest $N$. diversicolor (Davey \& George 1986).

Nereis diversicolor can avoid predators by remaining deep in their burrows, but while feeding, predation risk is increased. The species has a wide range of food size, from macrozoobenthos to microfauna and diatoms, but it also takes organic debris (Goerke 1971, Reise 1979, Witte \& de Wilde 1979). A wide array of different feeding techniques is used: filter feeding (Harley 1950, 1953, Goerke 1966, 1971), deposit feeding (Linke 1939, Goerke 1971, Reise 1979, Cram \& Evans 1980), scavenging (Vader 1964, Muus 1967, Green 1968,
Goerke 1971, this paper) and predation on other macrozoobenthos (Reise 1979, Witte \& de Wilde 1979, Ratcliffe et al. 1981, Ronn et al. 1988). The last 3 techniques have in common that the worm usually emerges from the burrow to feed at the surface. It is then an easy prey, being both detectable and accessible to predators. A filter-feeding worm spends about half of its feeding time near the surface, viz. during the construction of the mucous net and during the consumption of this net after irrigation (Harley 1953, Goerke 1966). During filtering (also known as mucous-bag feeding), a worm is thus accessible to most of its predators, but how risky filtering is depends on detectability.

In this paper, we analyse some factors determining burrow depth in Nereis diversicolor and discuss its importance for avoidance of predators. Further we present data on surface feeding and filter feeding and discuss the increased predation risks associated with both feeding methods.

\section{METHODS}

Study area. Research was carried out on the intertidal flats along the Frisian coast (1980 to 1985) and in the Dollart (1985), both situated in the eastern part of 
the Dutch Wadden Sea. The salinity is 25 to $30 \% \mathrm{~S}$ along the Frisian coast and fluctuates between 1 and $10 \% \mathrm{~S}$ in the southern part of the Dollart. The tidal range in the 2 areas is 1.6 to $2.5 \mathrm{~m}$ and 2.0 to $3.5 \mathrm{~m}$, respectively. Most study plots were situated just below mean sea level. The clay content $(<2 \mu \mathrm{m})$ was determined for the upper $25 \mathrm{~cm}$ of the sediment as weight fraction of the dried sample.

Burrow depth. Sediment cores, taken with a sampler (15 cm diameter, $40 \mathrm{~cm}$ deep), were solid enough to remain standing on an improvised table after the sampler was lifted. Cores were placed horizontally with the top against an upright shelf and broken sideways. The burrows of Nereis diversicolor were easy to locate, because they were surrounded by a light coloured oxidation layer and their inner wall looks smooth or even mucous (Linke 1939, Vader 1964). Most of the burrows had the shape of a $\mathrm{U}$, less often a $\mathrm{J}$ and occasionally a $\mathrm{Y}$. The worms were usually found in the deepest part of their burrow, sometimes doubled up. Burrow depth was measured to the nearest $0.5 \mathrm{~cm}$, as the distance between the surface and the deepest point of the burrow. A pin was used to correct for a possible loss of the upper layer of the substrate, usually not more than $0.5 \mathrm{~cm}$ (Zwarts 1986, Zwarts \& Wanink 1989).

Nereis diversicolor $<3 \mathrm{~cm}$ appeared to be missed frequently with the method described above. The depth of these small worms was measured with another technique on 2 sampling occasions: the upper $4 \mathrm{~cm}$ of the sediment core was cut into slices of $1 \mathrm{~cm}$, which were sieved separately on a $225 \mu \mathrm{m}$ sieve.

Body length, body weight and body condition. The length of Nereis diversicolor was measured in 3 ways: (1) the maximal length of a worm creeping along a ruler in seawater, (2) length of worms preserved in $60 \%$ alcohol and (3) length of worms stored in 10 to $20 \%$ formalin. The length of worms killed in alcohol or formalin was adjusted to the size of living worms (Table 1). The length of broken worms was estimated from the

Table 1. Nereis diversicolor. Relative body length when preserved in alcohol and formalin as compared to measurements of worms still alive $(=100 \%$ : maximal length of worms creeping along a ruler in seawater)

\begin{tabular}{|c|c|c|c|c|}
\hline & $\%$ & \pm- & $\mathrm{SD}$ & $\mathrm{n}$ \\
\hline Alcohol & 77.8 & \pm & 10.1 & 431 \\
\hline Formalin & 68.1 & \pm & 17.7 & 63 \\
\hline
\end{tabular}

relation between the width of the tenth segment and the length of intact worms (Fig. 1).

Ash-free dry weight (AFDW) was determined after the worms were dried at least $24 \mathrm{~h}$ at $70^{\circ} \mathrm{C}$ and subsequently ignited $2 \mathrm{~h}$ at $550^{\circ} \mathrm{C}$. Only freshly collected

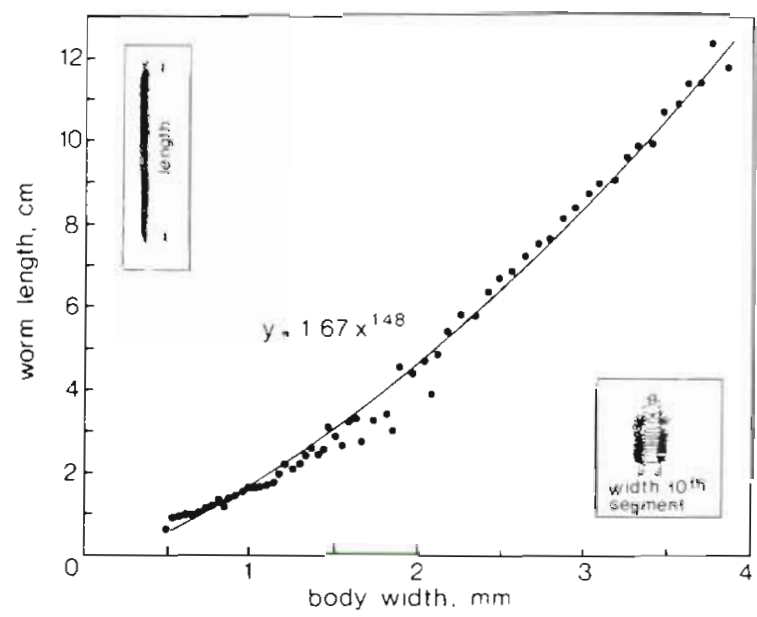

Fig. 1. Nereis diversicolor. Body length as a function of body width. The calculated relation was used to estimate the length of broken worms. Results of the regression analysis: $\mathrm{R}^{2}=96.7 \%, \mathrm{p}<0.001, \mathrm{n}=1014$

specimens were selected, since there was a considerable reduction of AFDW when Nereis diversicolor were stored in formalin or alcohol (Zwarts 1988). Body condition is defined as the deviation from expected body weight, which was derived from the allometric relationship between body length and AFDW as determined per sampling programme.

Feeding behaviour. The activity pattern of Nereis diversicolor in the field and in the laboratory was studied in September and October 1981 and 1985.

Field observations: Worm activity at the surface was observed continuously in 16 plots of $73 \mathrm{~cm}^{2}$ during 5 low water periods. Observations were made from a plank bridge to prevent disturbance of the worms. Two categories of activity were distinguished (Goerke 1971, Evans \& Rogers 1978, Cram \& Evans 1980): (1) 'Surface feeding', when at least the head was out of the burrow. The time spent at the surface was measured to the nearest second. (2) 'Inactive', when no worm was visible in a burrow entrance. The density and size frequency of the worms in the plots were determined afterwards with the core sampler.

Aquarium observations: An aquarium was filled with $15 \mathrm{~cm}$ of mud and divided into 12 compartments $(10 \times 25 \mathrm{~cm})$ with the aid of fine-mesh wire-netting. Each compartment contained 1 worm of 7 to $10 \mathrm{~cm}$ length. Tides were simulated by alternately pumping a water column of $15 \mathrm{~cm}$ into and out of the aquarium at intervals of $6 \mathrm{~h}$. The worm's food supply was undoubtedly low as the aquarium was poorly lit and the sea water was changed only once a week. Worm activity was recorded by observing the surface of one compartment continuously for 12 periods of $30 \mathrm{~min}$ and measuring the time spent at the surface ('surface activity'; as in the field situation) and the time spent on 'burrow activ- 
ity', as determined by air-bubbling, visible water currents or fluctuating water levels in one or both entries of the burrow, without the worm being seen (Twisk 1986). Burrow activity, which was not distinguished in the field, included filter feeding, irrigating for respiration and also crawling and turning round in the burrow (see Evans \& Rogers 1978 for a detailed description).

Analysis. SPSS (Nie et al. 1975) was used for all statistical analyses. The depth measurements throughout the year are shown per month, but where taken together per season, 'summer' and 'winter' are defined as the periods 16 May to 30 September and 15 November to 31 March respectively; 'spring' and 'autumn' are the 2 intervening $6 \mathrm{wk}$ periods.

\section{RESULTS}

\section{Burrow depth in relation to body length, substrate and season}

Nereis diversicolor lived in burrows 1 to $29 \mathrm{~cm}$ deep (Fig. 2). Average burrow depth increased with worm size but tended to level off for the larger size classes. There was a large variation in burrow depths for worms of the same size: $N$. diversicolor $>10 \mathrm{~cm}$ were usually found at a depth of 10 to $14 \mathrm{~cm}$, but some lived in shallow burrows of only 3 to $4 \mathrm{~cm}$, whereas others had burrows as deep as 24 to $29 \mathrm{~cm}$.

Worms of $<3 \mathrm{~cm}$ were found predominantly in the upper 2 to $3 \mathrm{~cm}$. The majority of $0.5 \mathrm{~cm}$ worms lived in burrows of 1 to $2 \mathrm{~cm}$. Size classes measured with the slice and core techniques show similar depths (Fig. 2 inset). According to Dales (1950) and Dales \& Kennedy (1954) larvae are present in the parent burrow or in the upper layer of the substrate, whereas worms of $4 \mathrm{~mm}$ are already able to construct their own U-shaped tubes. We found worms of this size class within the upper $2 \mathrm{~cm}$ in late summer (Fig. 2) and in October even in the upper $4 \mathrm{~cm}$ (Esselink \& van Belkum unpubl.).

Worms of a similar size buried deeper in sand than in mud (Fig. 2; Table 2). The difference is 2 to $3 \mathrm{~cm}$ and is almost independent of worm size. Worms buried more deeply in winter than in summer, in sand as well as in mud (sediments with a clay content of $\leq 5 \%$ and $\geq 6 \%$ respectively) (Fig. 3; Table 3). Small worms increased their depth by about $2 \mathrm{~cm}$ and the larger ones by about $5 \mathrm{~cm}$ in winter as compared with summer.

Fig. 4 shows the relationship between clay content and burrow depth. Burrow depth appeared to remain constant if the clay content increased from 6 to $20 \%$. However, in sediments with a clay content of $\leq 5 \%$ (defined above as sand) burrow depth increased when clay content decreased from 5 to $2 \%$. Nereis diver-

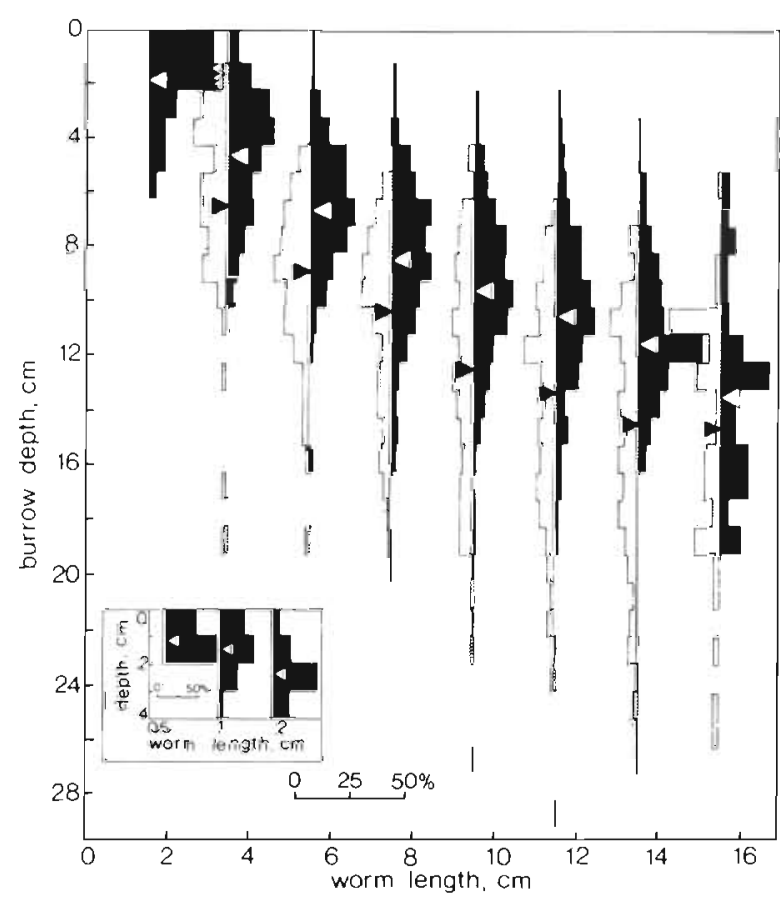

Fig. 2. Nereis diversicolor. Burrow depth in relation to body size in mud (clay content $\geq 6 \%, \mathrm{n}=1496$ ) (black; white arrow indicates the mean burrow depth per size class); and sand (clay content $\leq 5 \%, \mathrm{n}=887$ ) (grey; black arrow indicates the mean burrow depth per size class), 16 May to 30 September. See Table 2 for statistical analysis. Inset shows depths of 54 worms in mud measured with the slice technique (see 'Methods')

Table 2. Results of a 2-way analysis of variance to test the effect of body size and clay content on burrow depth during summer ( $\mathrm{n}=2383$; same data as Fig. 2)

\begin{tabular}{|lrc|}
\hline Source of variation & $\mathrm{R}^{2}(\%)$ & $\mathrm{p}$ \\
\hline Main effects & 53.0 & 0.001 \\
Body length & 33.5 & 0.001 \\
Clay content & 6.4 & 0.001 \\
Two-way interaction & 0.7 & 0.001 \\
\hline
\end{tabular}

sicolor are not found in sediments where the clay content is well under $1 \%$ (Zwarts 1988). The relationship between clay content and burrow depth in the sandy sediments was more pronounced in September than in June (Fig. 4). The effect of clay content on burrow depth cannot be attributed to other measured variables, such as elevation (or emersion time).

\section{Burrow depth and body condition}

The large variation in burrow depth for individuals of the same size (Fig. 2) can be explained partly by a 


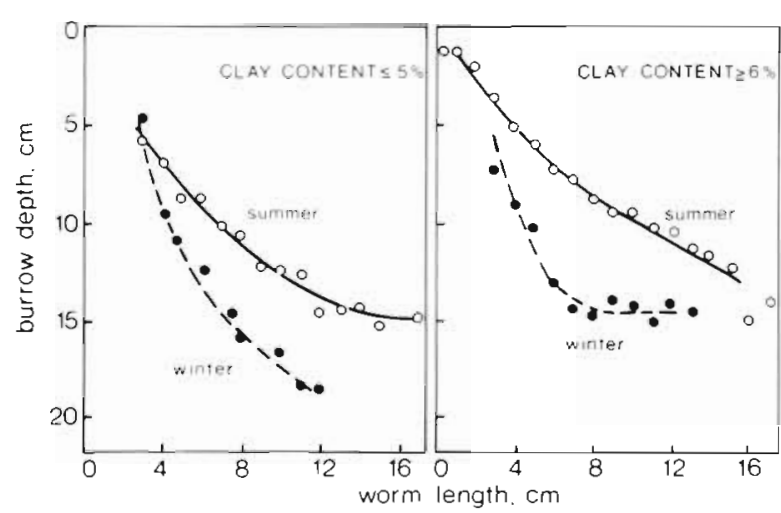

Fig. 3. Nereis diversicolor. Burrow depth as a function of body length during summer and winter in sand (left panel; $\mathrm{n}=887$ and 49, respectively) and mud (right panel; $\mathrm{n}=1496$ and 293, respectively). The lines are based on third degree polynomials. See Table 3 for statistical analyses

Table 3. Results of two 2-way analyses of variance to test the effect of body size and season on burrow depth in sand and mud (same data as Fig. 3)

\begin{tabular}{|lrcrc|}
\hline & \multicolumn{4}{c}{ Clay content } \\
& \multicolumn{2}{c}{$\leq 5 \%$} & \multicolumn{2}{c|}{$\geq 6 \%$} \\
Source of variation & $\mathrm{R}^{2}(\%)$ & $\mathrm{p}$ & $\mathrm{R}^{2}(\%)$ & $\mathrm{p}$ \\
\hline Main effects & 28.2 & 0.001 & 63.0 & 0.001 \\
Body size & 25.8 & 0.001 & 40.2 & 0.001 \\
Season & 4.0 & 0.001 & 16.9 & 0.001 \\
Two-way interaction & 1.0 & 0.261 & 0.8 & 0.001 \\
\hline
\end{tabular}

difference in body condition (Fig. 5). The body weight of deep-living Nereis diversicolor was on average 2 to 3 times greater than that of individuals of the same size class with shallow burrows. Apparently, worms in good condition are able to maintain deeper burrows.

It is known that body condition varies throughout the year and also differs for worms found along the tidal gradient (Chambers \& Milne 1975, Esselink et al. 1989). Fig. 5 shows that the body condition of worms living in sand was 10 to $35 \%$ higher than that of individuals sampled in mud. The effect of clay content on burrow depth, as described in the previous section, disappears completely in 3 out of 4 sampling programmes if body condition is taken into account (Table 4). The deeper burrows found in sandy sediments might thus be explained by the average difference in body weight between individuals inhabiting sandy and muddy sediments.

There is also a positive relationship between body condition and burrow depth when worms within the same season are compared, but this effect appears to be independent of the seasonal variation in depth (Fig. 6; Table 5).

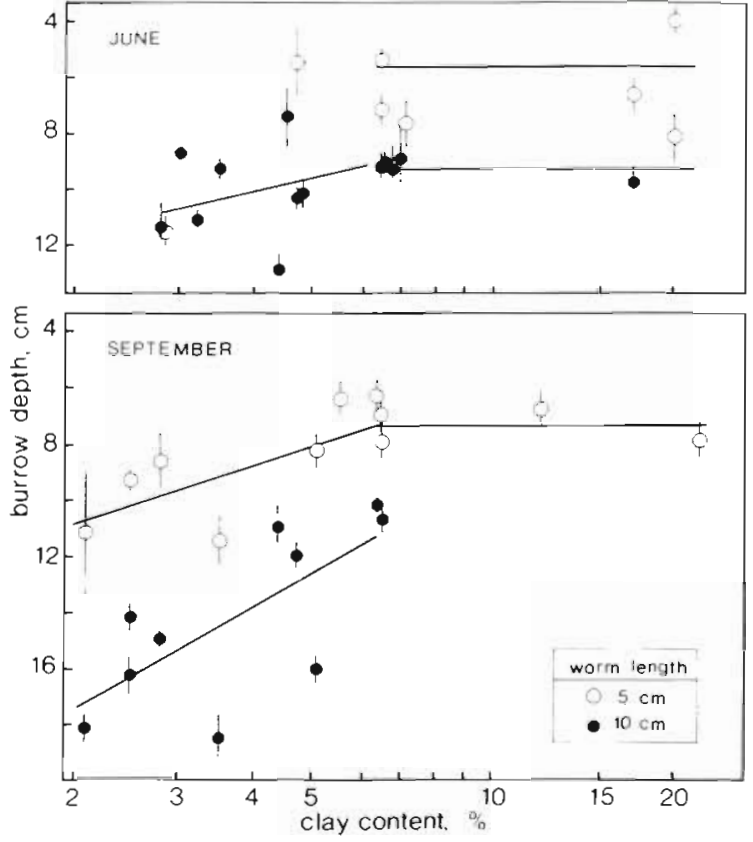

Fig. 4. Nereis diversicolor. Burrow depth (mean $\pm \mathrm{SE}$ ) in relation to clay content of the sediment for worms of 5 ( 4 to 6 ) and $10(7$ to 14$) \mathrm{cm}$ in June ( $\mathrm{n}=1138$ and 51, respectively) and in September ( $n=642$ and 189 , respectively). Mean depth is given for substrate with clay content $\geq 6 \%$. Since there is an increase of depth with size within the selected ranges (cf. Fig. 2), a correction was made to transform the depth measurements of worms of 4 to 6 and 7 to $14 \mathrm{~cm}$ to the burrow depth of a standard worm of 5 and $10 \mathrm{~cm}$, respectively

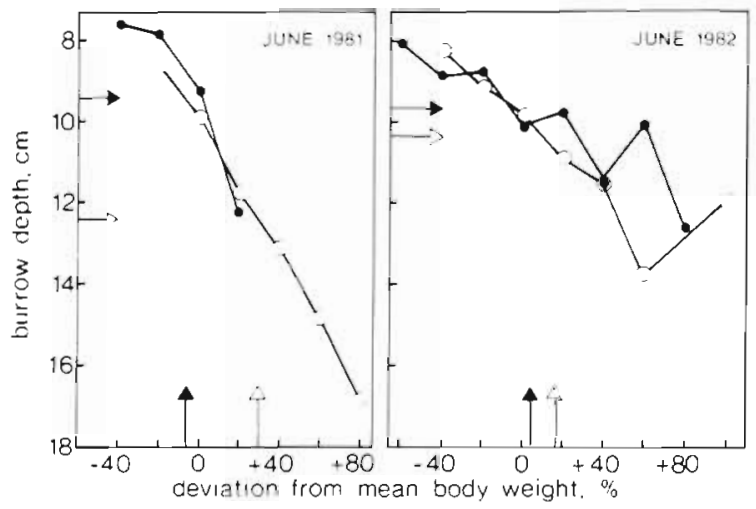

Fig. 5. Nereis diversicolor. Burrow depth of worms of 10 (7 to 14) $\mathrm{cm}$ living in mud (•) and sand (O) as function of body condition in 2 sampling programmes. Mean burrow depth and mean body condition in mud and sand are indicated by black and white arrows, respectively. A correction has been made, as in Fig. 4, to adjust for the size effect on depth. See Table 4 for statistical analysis

\section{Burrow depth in relation to season and temperature}

There was a great difference in burrow depth between summer and winter for all size classes (Fig. 3). 
Table 4. Results of four 2-way analyses of variance to test the effect of bady condition and clay content on burrow depth in 4 sampling programmes (data for June and July shown in Fig. 5). Since body condition is related to clay content, the total variance explained by the 2 main effects can be larger than the sum of the variances unique to each of the separate factors

\begin{tabular}{|c|c|c|c|c|c|c|c|c|}
\hline \multirow{2}{*}{$\begin{array}{l}\text { Source of } \\
\text { variation }\end{array}$} & \multicolumn{2}{|c|}{$\begin{array}{l}\text { Nov } 1980 \\
(\mathrm{n}=55)\end{array}$} & \multicolumn{2}{|c|}{$\begin{array}{l}\text { Apr } 1981 \\
(\mathrm{n}=67)\end{array}$} & \multicolumn{2}{|c|}{$\begin{array}{c}\text { Jun } 1981 \\
(\mathrm{n}=91)\end{array}$} & \multicolumn{2}{|c|}{$\begin{array}{l}\text { Jul } 1982 \\
(\mathrm{n}=299)\end{array}$} \\
\hline & $\mathrm{R}^{2}(\%)$ & $\mathrm{p}$ & $\mathrm{R}^{2}(\%)$ & $p$ & $\mathrm{R}^{2}(\%)$ & $\mathrm{p}$ & $\mathrm{R}^{2}(\%)$ & $\mathrm{p}$ \\
\hline Main effects & 36.0 & 0.001 & 27.2 & 0.001 & 54.2 & 0.001 & 11.9 & 0.001 \\
\hline Condition & 8.0 & 0.002 & 25.0 & 0.001 & 2.0 & 0.001 & 10.4 & 0.000 \\
\hline Clay content & 7.5 & 0.020 & 4.4 & 0.055 & 0.0 & 0.876 & 0.7 & 0.118 \\
\hline Two-way interaction & 0.2 & 0.734 & 3.7 & 0.206 & 0.4 & 0.718 & 2.3 & 0.190 \\
\hline
\end{tabular}

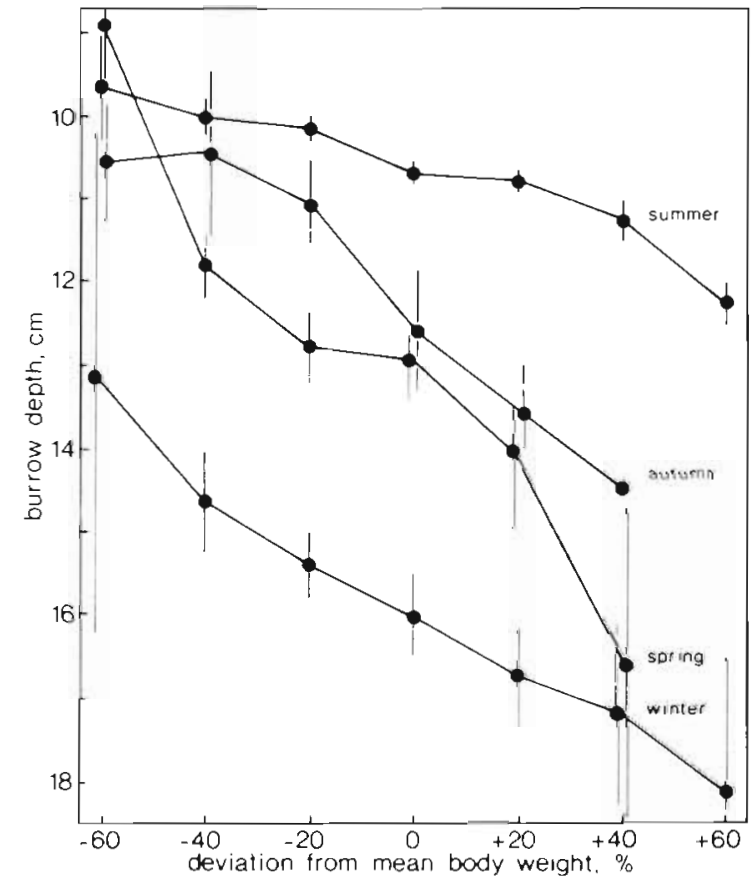

Fig. 6. Nereis diversicolor. Burrow depth (mean $\pm \mathrm{SE}$ ) of worms of $10(7$ to 14$) \mathrm{cm}$ as a function of body condition in 4 seasons ( $n=2247$ ); sites with different clay content are taken together. As in Fig. 4 and 5 a correction was made to adjust for the size effect on depth. See Table 5 for statistical analysis

Fig. 7 shows the burrow depth of Nereis diversicolor of $10 \mathrm{~cm}$ over a number of years. There is a large similarity between the years: burrow depth was maximal in January or February, followed by a decrease of $2 \mathrm{~cm}$ per month until the minimal depth was reached in June or July. Then, in late summer, burrow depth gradually began to increase again with an acceleration after October.

Variations in burrow depth throughout the year correspond with day length, but there is a better correlation between depth and sea water temperature (Fig. 7). Fig. 8 shows a curvilinear relationship between sea water temperature and burrow depth. Burrow depth appears to depend on temperature, independent of the
Table 5. Results of a 2-way analysis of variance to test the effect of body condition and season on burrow depth ( $\mathrm{n}=$ 2247; same data as Fig. 6)

\begin{tabular}{|lcc|}
\hline Source of variation & $\mathrm{R}^{2}(\%)$ & $\mathrm{p}$ \\
\hline Main effects & 29.5 & 0.001 \\
Season & 27.1 & 0.001 \\
Condition & 3.5 & 0.001 \\
Two-way interaction & 0.9 & 0.242 \\
\hline
\end{tabular}

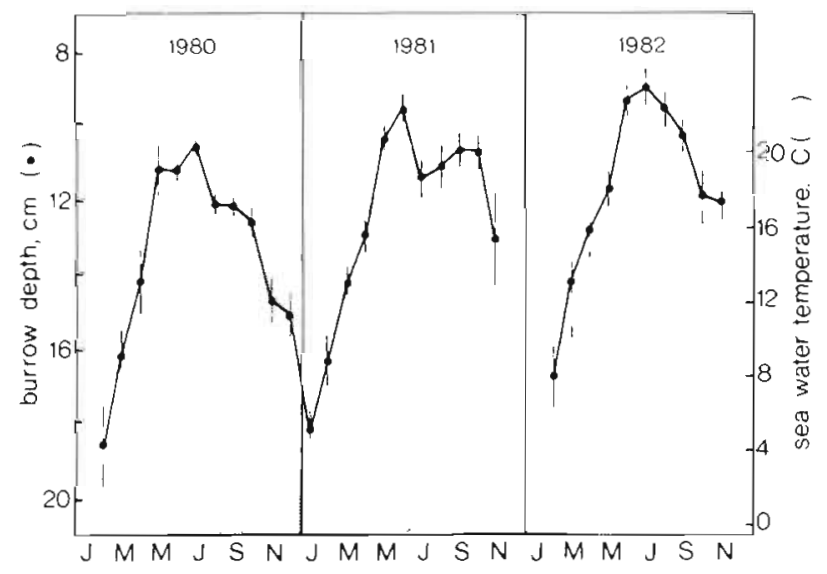

Fig. 7. Nereis diversicolor. Seasonal variation in burrow depth (mean $\pm \mathrm{SE}$ ) of worms of $10 \mathrm{~cm}(7$ to $14 \mathrm{~cm}$, with transformation as in Fig. 4), living in mud (clay content $\geq 6 \%$ ). Sea water temperatures on the sampling dates are taken from the series of daily measurements of Rijkswaterstaat at Holwerd

time of year; an analysis of covariance (not shown) confirmed this

All burrows were found in the upper $30 \mathrm{~cm}$, even in winter, and since a core sampler of $40 \mathrm{~cm}$ was used, the possibility of deeper burrows was eliminated. The fact that burrow depth correlates well with sea water temperature (Figs. 7 and 8 ) suggests that low temperatures stimulate Nereis diversicolor to deepen their burrows. The only time we observed remarkable digging activity by $N$. diversicolor was after a sudden drop in tempera- 


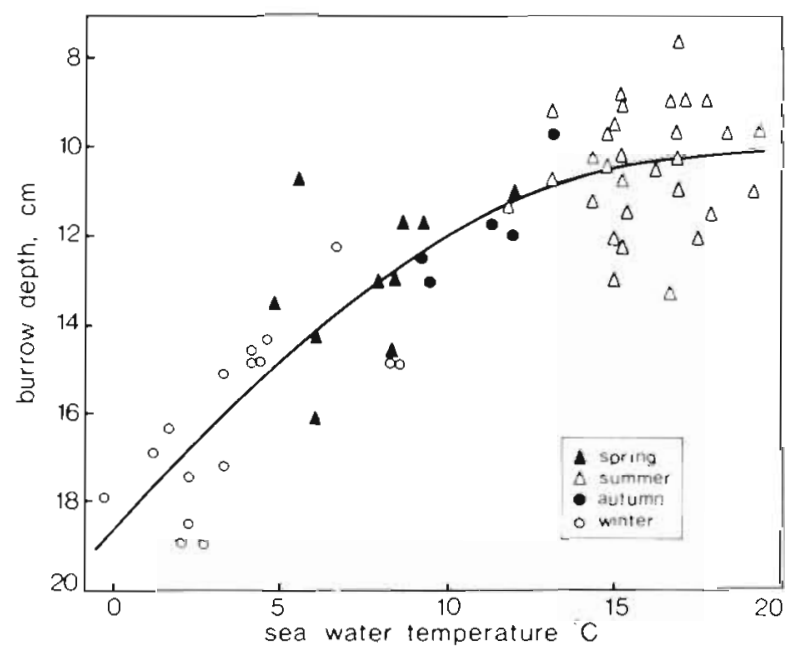

Fig. 8. Nereis diversicolor. Burrow depth of worms of $10 \mathrm{~cm}$, living in mud (clay content $\geq 6 \%$ ), as a function of sea water temperature, given separately for the 4 seasons $(61$ sampling days from 1980 to 1985 ). Line based on second degree polynomial $\left(\mathrm{R}^{2}=77.6 \%, \mathrm{p}<0.001, \mathrm{n}=61\right)$

ture (to below $0^{\circ} \mathrm{C}$ ) in October, when the burrows were deepened by an average of $2 \mathrm{~cm}$.

Linke (1939) and Beukema (1979 and pers. comm.) found very deep burrows of ca $40 \mathrm{~cm}$ in the Wadden Sea after a cold spell during which the upper layer of the mud was frozen. Muus (1967) measured the burrow depth of $N$. diversicolor in Niva Bay, Denmark. The winter temperature there is lower than in the Wadden Sea, and in February he indeed found most large worms at a depth of $40 \mathrm{~cm}$ and some even at 50 to 60 $\mathrm{cm}$. The depth distribution in summer does not differ between Nivå Bay (0 to $20 \mathrm{~cm}$; Muus 1967) and the Wadden Sea (5 to $25 \mathrm{~cm}$, according to Thamdrup (1935) and this study (Fig. 2).

\section{Feeding behaviour in the field}

We spent 5 low water periods during daylight in the field recording the activity of Nereis diversicolor. No activity at all was observed during 2 days in September on a tidal flat with a mixed substrate (clay content $5 \%$ ), though the worm density was high (95 worms $\mathrm{m}^{-2}$ ) and the mud temperature not low $\left(19^{\circ} \mathrm{C}\right)$. The surface activity varied significantly from day to day as well as during the low water period on a mudflat where the clay content amounted to $25 \%$ (Fig. 9). Worms appeared at the surface there at an average of $2.4,0.7$ and 0 times during 3 low water periods in September and October (Fig. 9A). This variation might be attributed to mud temperature, which averaged 20,17 and $11^{\circ} \mathrm{C}$, respectively. The mean duration of the surface
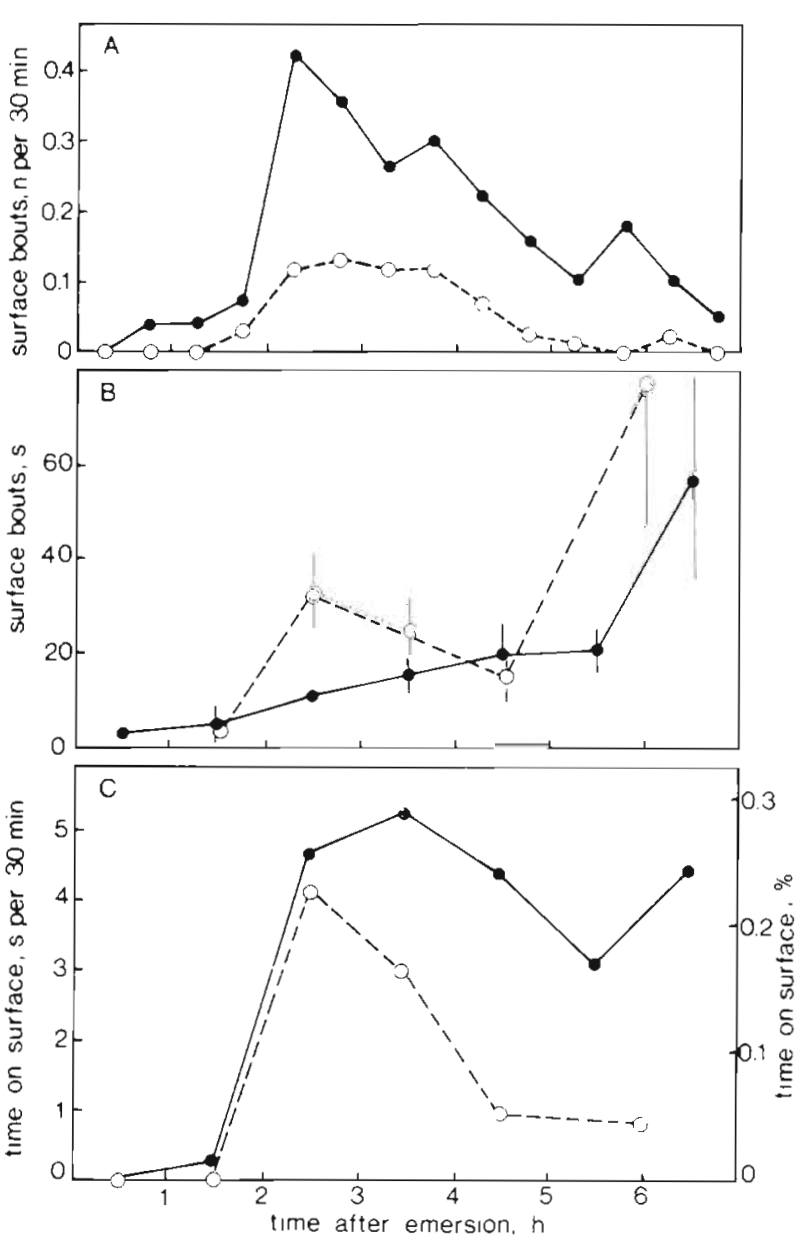

Fig. 9. Nereis diversicolor. Surface activity on a muddy intertidal flat after emersion on 9 September $(\bullet)$ and 22 September (o). (A) Frequency with which worms $\geq 3 \mathrm{~cm}$ were observed at the surface (freq. $=$ no. of observations/mean density; it was assumed that worms $<3 \mathrm{~cm}$ were not detected). (B) Duration of the surface bouts (mean \pm SE). (C) Surface activity as percentage of the time budget (freq. $h^{-1} \times$ duration of surface bout)

bouts also varied between days; on the first day it was $17.6 \mathrm{~s}$ and $11 \mathrm{~d}$ later it was $27.3 \mathrm{~s}$ (Fig. 9B).

For both days there was a similar tidal trend in the frequency with which Nereis diversicolor appeared at the surface, as well as in the duration of the surface bouts. Almost no worms came to the surface during the first $2 \mathrm{~h}$ after the mudflat emerged. The peak frequency occurred in the third hour with a gradual decline afterwards. The frequency was again very low during the last 1 to $2 \mathrm{~h}$ that the mudflat was exposed. In contrast to the frequency, the duration of the surface bouts increased during the course of the emersion period (Fig. 9B). The length of the surface bouts ranged from 0.5 to $14 \mathrm{~s}$ during the first $2 \mathrm{~h}$ after emersion and $50 \%$ lasted less than $4 \mathrm{~s}$. This is in great contrast to the last $2 \mathrm{~h}$ of the emersion time, when only $40 \%$ of the bouts 
were less than $15 \mathrm{~s}$ and ca $20 \%$ of the feeding bouts exceeded $60 \mathrm{~s}$. A similar tidal trend in the feeding behaviour was measured in May (Twisk 1986), but the overall level of activity was higher than in late summer.

Nereis diversicolor spent 0.1 to $0.2 \%$ of the emersion phase at the surface (Fig. 9C), i.e. an average of 25 to 50 s per individual. There was, however, a large variation in the time individuals spent on the surface. It was estimated that half the worms remained in their burrow on the first day of observation, while others spent $300 \mathrm{~s}$ and more at the surface.

\section{Feeding behaviour in an aquarium}

Nereis diversicolor were never observed at the surface during high water. Worms appeared 6 times per hour at the surface during low water conditions ( 12 half hours of continuous observation), which is 15 to 50 times the frequency in the field (Fig. 9A). The average bout length $(63.7 \mathrm{~s}, \mathrm{n}=36)$ was ca $7 \times$ longer in the aquarium than in the field (Fig. 9B). Consequently much more time was spent at the surface in the aquarium (Fig. 10A) than in the field situation, possibly because in the aquarium the food concentration in the water was much lower. A total feeding time of ca $20 \%$ during the low water period of $6 \mathrm{~h}$ is ca 10 times more than that measured by Twisk (1986) in a more natural experimental setting.

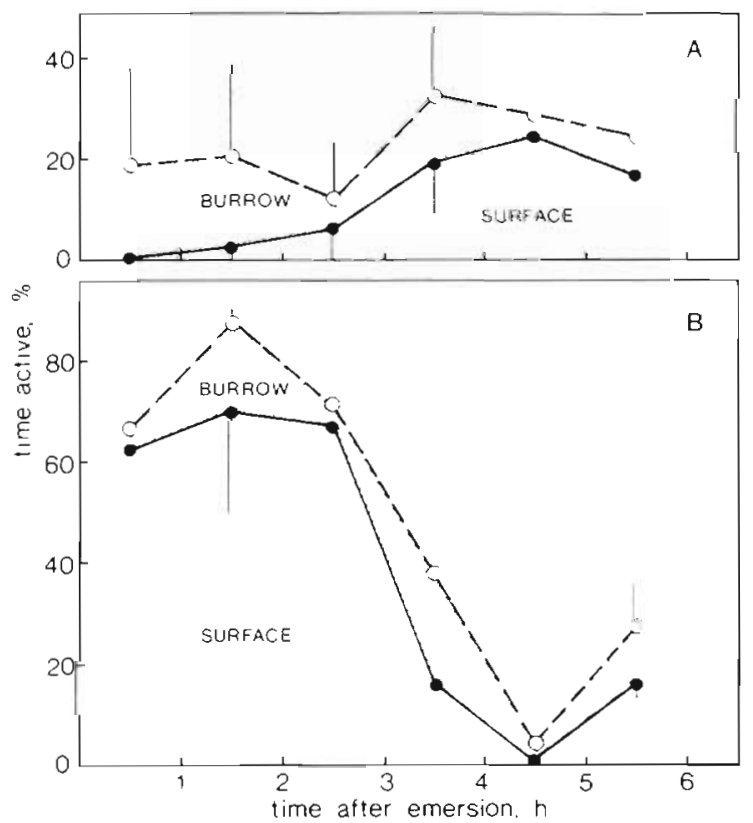

Fig. 10. Nereis diversicolor. Time-budget in an aquarium after exposure; active at surface (open area) and in burrow (grey). (A) Control; (B) feeding experiment when a slurry of minced Scrobicularia plana was poured over the substrate just after emersion. Standard errors computed per half hour periods

$$
(\mathrm{n}=12)
$$

The surface activity was, as in the field situation, minimal during the first $2 \mathrm{~h}$ after exposure, but the burrow activity was then at its maximum (ca 20\%). The time spent on burrow activity decreased during the low water period, whereas surface activity increased, resulting in an almost constant level of observed activity during the entire exposure time. This pattern of activity changed completely after a slurry of shelled and minced Scrobicularia plana was poured over the mud shortly after emersion (Fig, 10B). Nereis diversicolor came to the surface immediately to scavenge on the pieces of meat, which they took down into their burrows. The worms spent most of their time at the surface during the first $3 \mathrm{~h}$ of this experiment. It is unlikely that the decrease in activity after $3 \mathrm{~h}$ was caused by a depletion of the food supply because of the large quantity of slurry used in the experiment. Possibly the worms became satiated.

There was no burrow activity when there was no water left at the surface (Fig. 11), as also found by

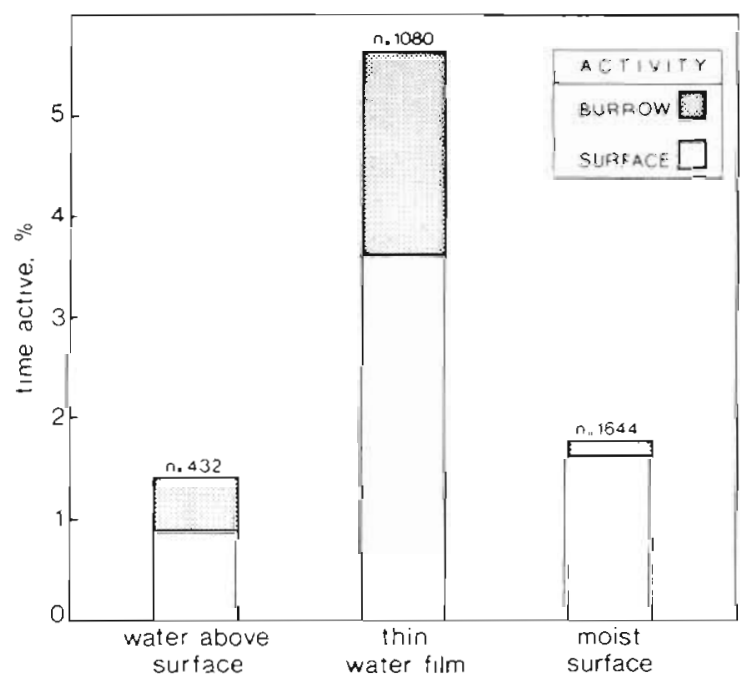

Fig. 11. Nereis diversicolor. Activity in an aquarium in relation to water level after exposure, based on activity counts every $10 \mathrm{~min}(\mathrm{n}=$ counts $\times$ worms in aquarium)

Twisk (1986). The observation that burrow activity was maximal if the overlying water layer was thin might be explained by the increasing food concentration when the depth of the water column decreased, but we cannot exclude the possibility that the burrow activity became more visible. The method used to obtain the activity data in Fig. 11 apparently led to an underestimation compared with the time-budget study (cf. Fig. $10 \mathrm{~A}$ ). This does not, however, change the relative differences in activity as caused by water level. 


\section{DISCUSSION}

\section{Burrow depth and size}

Burrow depth of Nereis diversicolor increased with size (Figs. 2 and 3). However, within each size class there was a large variation in burrow depth. A part of this variation can be attributed to body condition: worms with a relatively heavy body weight have deeper burrows than worms in poor condition (Figs. 5 and 6). The difference in burrow depths of worms living in sand and mud (Figs, 2 to 4) might also be explained by systematic differences in body condition for worms living in sand and mud (Fig. 5). There is no reason to assume that deep burrows cause enhanced body condition, so the reverse seems more likely: worms with a poor condition are apparently not able to dig and/or maintain a deep burrow. In bivalves it was also found that individuals with a better body condition increase their burying depth, achieving a decrease in their predation risk (Zwarts 1986, Zwarts \& Wanink 1989).

\section{Burrow depth and predation risk}

When the tidal cycle is simulated in a laboratory, worms remain deep in their burrows and perform no surface activity during immersion (Vader 1964, this paper). If this is also the case in the field, depth would determine accessibility to shrimp and fish feeding when the tidal flats are flooded. Shrimp Crangon crangon and fish (e.g. Potamoschistus microps and Platichthys flesus) do not dig deeply and must capture Nereis diversicolor from near or at the surface. The larger the shrimp the larger the worm taken, to a maximum of $3 \mathrm{~cm}$ (Pihl \& Rosenberg 1984). P. microps are able to kill and eat an adult $N$. diversicolor, but mainly take the smallest worms in the field (Muus 1967). There is no information available on size selection by flounder $P$. flesus, but since they make feeding holes of only a few $\mathrm{cm}$ (Summers 1980), a restriction to the smaller size classes is to be expected. $N$. diversicolor, however, are an unimportant prey for $P$. flesus or plaice Pleuronectus platessa in the Wadden Sea (de Vlas 1979), in contrast to the situation elsewhere (Muus 1967. Pihl 1982). Baird \& Milne (1981) calculated that in the Ythan estuary (Scotland), for example, 60"he total production of $N$. diversicolor was consumed by predators, of which $1 / 3$ was taken by flatfish and the other $2 / 3$ by 3 bird species: shelduck Tadorna tadorna, redshank Tringa totanus and oystercatcher Haematopus ostralegus.

Nereis diversicolor present at the surface during low water retreat quickly when disturbed (Linke 1939, Vader 1964, own obs.). The frequency distribution of burrow depth, as given for the different size classes
(Fig. 2) can therefore be used to calculate accessibility to predators which dig or probe to a certain depth.

The maximum probing depth of waders, as determined by bill length, varies from $3 \mathrm{~cm}$ (dunlin Calidris alpina, grey plover Pluvialis squatarola) to 15 or $16 \mathrm{~cm}$ (female curlew Numenius arquata). In winter all burrows of Nereis diversicolor $\geq 5 \mathrm{~cm}$ in body length are deeper than $4 \mathrm{~cm}$, thus greater than the bill length of dunlin or grey plover (Fig. 12A). The first species

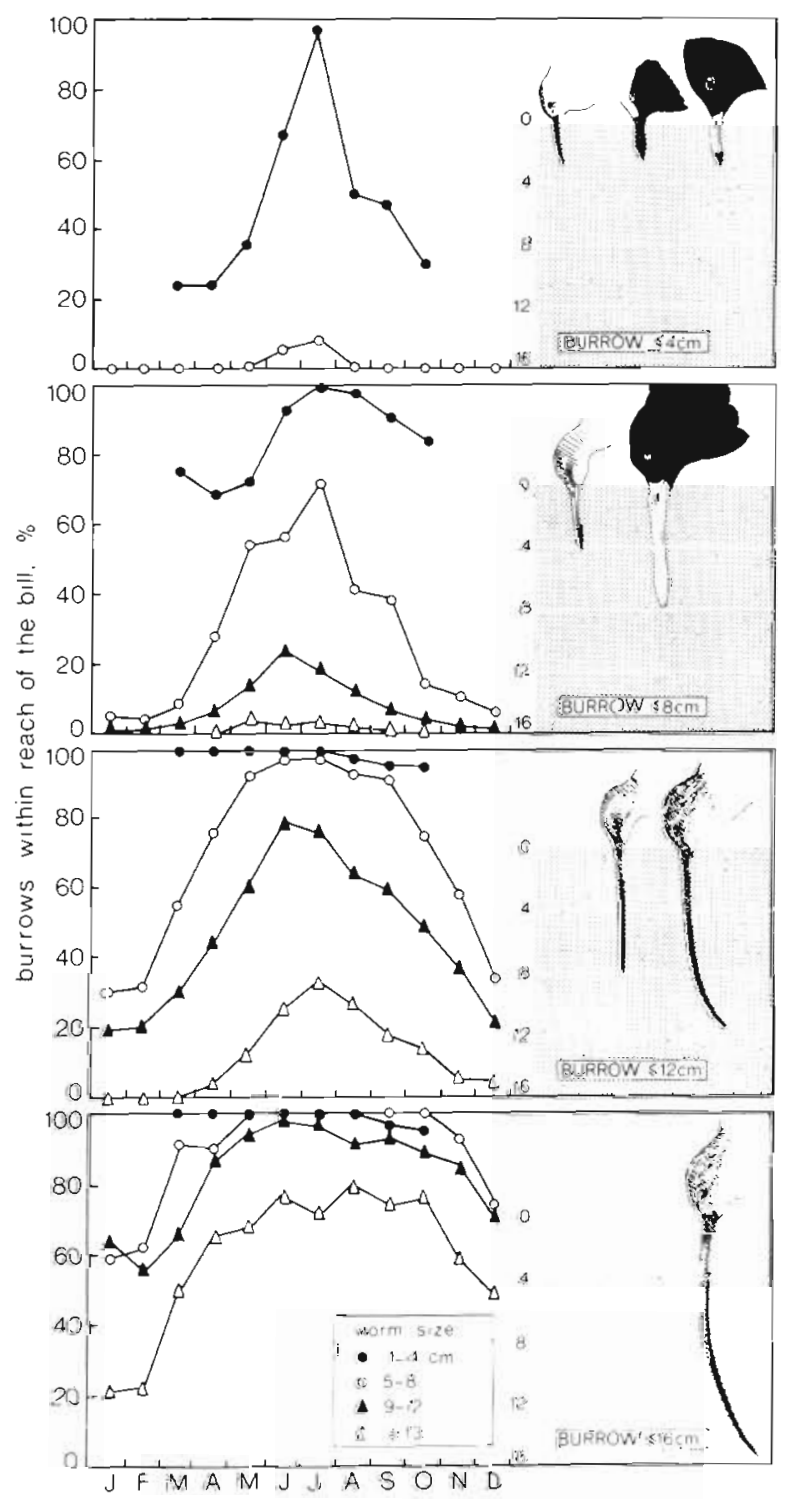

Fig. 12. Annual variation in the accessibility of 4 size classes of Nereis diversicolor to predators with different bill lengths, as calculated from the frequency distribution of the burrow depths in mud (cf. Figs. 2 and 3). The panels show from top to bottom the accessible fraction in the range 0 to $4 \mathrm{~cm}$ (within reach of e.g. dunlin, grey plover and black-headed gull), 0 to 8 $\mathrm{cm}$ (within reach of e.g. redshank and oystercatcher). 0 to 12 $\mathrm{cm}$ (within reach of $\%$ bar-tailed godwit and $\delta \delta$ curlew) and 0 to $16 \mathrm{~cm}$ (within reach of 9 curlew) 
indeed selects $N$. diversicolor $\geq 4 \mathrm{~cm}$ in winter (Worrall 1984). Kersten \& Piersma (1984) found that grey plover took 2.5 and 5 worm min $^{-1}$ in May and September, respectively, and calculated that grey plovers had to take worms of 5 to $7 \mathrm{~cm}$, the most common size class present in the mud, to meet their energy demands. Evans et al. (1979) observed that most grey plovers wintering in the Tees estuary (NE England) took the larger $N$. diversicolor. Grey plovers must, therefore, rely on worms present in or at the burrow entrance. This must also be the case with most other short-billed wader and gull species. Observations on the feeding behaviour of black-headed gull Larus ridibundus (Curtis et al. 1985) and curlew (Zwarts \& Esselink 1989) show that these birds take most $N$. diversicolor from the surface.

Avocet Recurvirostra avosetta sweep their bill through the upper layer of the surface and nevertheless take large Nereis diversicolor (Tjallingii 1969, Engelmoer \& Blomert 1985). The intake rate of avocets in the course of the emersion period closely resembles the tidal trends in surface feeding of $N$. diversicolor as shown in Fig. 9 (own obs.). In winter redshank (bill length $4 \mathrm{~cm}$ ) prey on worms larger than $4 \mathrm{~cm}$ (GossCustard 1969, 1977a, b), which would be unavailable if they remained deep in their burrows (Fig, 12b).

Most worms caught by curlews are $\geq 9 \mathrm{~cm}$. The fraction of this size class accessible to a probing male curlew (bill length $12 \mathrm{~cm}$ ) is $80 \%$ in summer against $20 \%$ in winter (Fig. 12C). In summer curlews feed on worms which are extracted from the burrows, while in winter nearly all worms are taken from the surface. Female curlews are the only predators which are able to probe to a depth of 13 to $16 \mathrm{~cm}$ (Fig. 12D). Worms below this danger line are out of reach of all their predators.

Apparently, the majority of the waders take worms from the surface. Most of these predators have no choice, since the burrow depth exceeds their bill length. Fig. 3 shows that burrow depth increases with worm size but that the depth levels off as soon as worms reach a critical depth below the maximal probing depth. The same has also been found in estuarine bivalves (Zwarts \& Wanink 1989). A simple explanation for this might be excessive predation pressure on all accessible worms. The creaming-off effect of predators taking worms from shallow burrows was studied with an exclosure experiment set up in July; after 2 mo a difference in average depth was apparent (worms inside the exclosure burrowed on average 0.5 $\mathrm{cm}$ shallower). This difference (although not statistically significant on account of small sample sizes) suggests that the critical depth of 12 to $15 \mathrm{~cm}$ is partly caused by selective predation on shallow-living worms.

\section{Seasonal variation in burrow depth}

There are 3 possible explanations for the seasonal variation in burrow depth (Fig. 7): predation pressure, temperature and feeding method.

Assuming that the selection of burrow depth has evolved so as to minimize predation risk, it is to be expected that a seasonal variation in predation pressure will correspond with a similar trend in burrow depth. It is indeed true that worms live at a minimal depth from May to mid July when most deepprobing predators (curlew, oystercatcher and bartailed godwit) are absent, but the burrows remain shallow after these waders return in July and are present in maximum numbers in August/September. Seasonal depth variation is thus not governed by predation pressure alone.

Temperature seems to be of overriding importance. In summer, mud temperature decreases with depth but the reverse is true when the surface temperature is ca $0^{\circ} \mathrm{C}$ (de Wilde \& Berghuis 1979 , Zwarts unpubl.). A deeper burrow in winter might therefore be an adaptation to escape low temperatures. Worms do indeed increase their depth at an average rate of $0.6 \mathrm{~cm}$ for a sea temperature drop of $1{ }^{\circ} \mathrm{C}$, at least below ca $15^{\circ} \mathrm{C}$ (Fig. 8). The digging activity of the worms after a frost in October, mentioned earlier in the text, can be interpreted as a direct effect of temperature on burrow depth. This observation also shows that the worms' adjustment of burrow depth is not continuous, but erratic.

A third seasonal effect might be prompted by the use of different feeding techniques. If the worm obtains all its food from the surface, the burrow is solely a refuge from predators and an adverse climate. During filter feeding, however, the burrow also serves as an irrigation channel. Irrigation is an energydemanding feeding technique (Kristensen 1981), but these costs are minimized if the burrow depth is reduced. It is therefore likely that, other things being equal, filter feeders burrow less deep than surfacefeeding worms. This effect is likely to be found only if filter feeding occurs predominantly at high sea water temperature, given the close relationship found between temperature and burrow depth. Though detailed information is lacking, it is true that filter feeding is rare in winter and very common in summer (Goerke 1971).

One can thus conclude that temperature is an important factor determining the seasonal variation in burrow depth. The possibility that filter feeding is more profitable if the burrow depth is reduced and that seasonal variation in the significance of filter feeding might effect the observed trends in burrow depth deserves further research. 


\section{Feeding and prey risk}

The choice of Nereis diversicolor to filter feed from the overlying water, to leave the burrow to feed at the surface, or to remain inactive in the burrow, depends on the trade-off between gain of energy and avoidance of predation. Though $N$. diversicolor is one of the best studied estuarine zoobenthic species, it is still impossible to describe this decision-making in a quantitative way, although some qualitative predictions can be made.

Nereis diversicolor respond immediately to a change in their food supply (Fig. 10), which suggests that they evaluate the current yield from filtering or surface feeding. The food supply in water and on the surfacelayer is different for worms living in mud and in sand. The surface layer contains more food on a mudflat than on a sandflat (Newell 1979), whereas filter feeding on muddy shores is probably less profitable or even impossible, because $N$. diversicolor probably meet the same problem as other filter feeders, viz. the relatively low concentration of food particles among all suspended material. More suspension feeding and less deposit feeding can therefore be expected if $N$. diversicolor living in sand are compared with those in mud. Our field observations indeed suggest that surface feeding is common in mud and absent on sandflats.

Filter feeding makes no sense when the food supply in the water is too low. The food supply is maximal in summer and minimal in winter, but this variation is much larger in the water than in the upper surface of the substrate (Colijn 1982, Hummel 1985), so it is to be expected that filter feeding disappears during the winter. Goerke (1971) indeed observed little filter feeding in winter, whereas it was very common in summer.

Filter feeding is impossible if no water remains at the surface (Twisk 1986), whereas surface feeding can occur regardless of the stage of the tidal cycle. However, worms exposed to a tidal regime do not feed at the surface during immersion (Vader 1964, this paper), probably to escape the high risk of being taken by fish. shrimps and crabs.

Filter feeding is not without danger because predators probably see the burrow entrances or even the water current or fluctuating water level at the entrance to the burrow (Twisk 1986). Moreover, filter-feeding Nereis diversicolor spend about half their time close to the surface, viz. during the construction of the mucous net and during the consumption of this net after irrigation (Harley 1953, Goerke 1966). Surface feeding is the most dangerous feeding technique, however, because the worm is very conspicuous and easy to catch. The likelihood of its escape from an approaching predator depends on how quickly it can retreat into the lower part of its burrow.
The time spent by Nereis diversicolor at the surface is very limited. Fig. $9 \mathrm{C}$ shows it was only 0.1 to $0.2 \%$ during low water in September and $0 \%$ during 2 other low water periods, also during late summer,

Birds feeding on exposed tidal flats take more worms from the surface than from burrows (Zwarts \& Esselink 1989), which means that the predation risk during surface feeding must be extremely high compared with a situation in which the worms remain in their burrows. Thus worms obtaining all their food from the surface (e.g. worms in soft mud) are exposed to a greater predation risk than worms which solely filter feed (e.g. worms in sand). The low body condition of worms in mud (Fig. 5) and the reduced growth in mud as compared with sand (Zwarts 1988) might therefore be the consequences of the counterbalancing of the enhanced predation risk.

The feeding rate (energy intake $\mathrm{s}^{-1}$ ) must be very high during surface bouts, compared with the feeding rate during filter feeding. The difference in energy gain between both techniques is even greater if one takes into account that the feeding costs of filtering are high (Kristensen 1981). Nevertheless, surface feeding is, in our view, a supplement to filter feeding, because of the very high predation risk it entails. Worms feed at the surface in 3 circumstances in which filter feeding is unprofitable or impossible: (1) during that phase of a tidal cycle when filter feeding is made impossible by lack of water on the surface (Fig. 11), (2) in winter when the low concentration of food in suspension makes filter feeding unprofitable, (3) on muddy shores where the relatively low amount of food in the suspended material makes filtering less profitable.

The density of Nereis diversicolor actually available to predators thus depends not only on the depth of their burrows but also on their own choice of feeding methods (Zwarts \& Esselink 1989).

Acknowledgements. Many people have participated in this research. We would especially like to mention Jaap van Belkum, Tonny van Dellen and colleagues, Hans Kleef and colleagues, Tjarda de Koe, Jan Komdeur and Jan Wanink. We also thank Rudj Drent for his supervision and Bruno Ens for many discussions; they, Karel Essink, John Goss-Custard and Victor de Jonge commented on the manuscript. All figures were prepared by Wieberen Planting. Jos Zwarts made the bird vignettes.

\section{LITERATURE CITED}

Baird, D., Milne, H. (1981). Energy flow in the Ythan estuary, Aberdeenshire, Scotland. Estuar coast. Shelf Sci. 13: $455-472$

Beukema, J. J. (1979). Biomass and species richness of the macrobenthic animals living on a tidal flat area in the Dutch Wadden Sea: effects of a severe winter. Neth. J. Sea Res. 13: 202-223 
Chambers, M. R., Milne, H. (1975). Life cycle and production of Nereis diversicolor O. F. Müller in the Ythan Estuary Scotland. Estuar. coast mar Sci. 3: 133-144

Colijn, F. (1982). Light absorption in the waters of the EmsDollard Estuary and its consequences for the growth of phytoplankton and microphytobenthos. Neth. J. Sea Res. 15: $196-216$

Cram, A., Evans, S. M. (1980). Stability and lability in the evolution of behaviour in nereid polychaetes. Anim. Behav. 28: $483-490$

Curtis, D. J., Galbraith, C. G., Smyth, J. C., Thompson, D. B. A. (1985). Seasonal variation in prey selection by estuarine black-headed gulls (Larus ridibundus). Estuar. coast. Shelf Sci. 21: 75-89

Dales, R. P. (1950). The reproduction and larval development of Nereis diversicolor O. F. Müller. J. mar. biol. Ass. U.K. 24: $321-360$

Dales, R. P., Kennedy, G. Y (1954). On the diverse colours of Nereis diversicolor. J. mar. biol. Ass. U.K. 33: 699-708

Davey, J. T., George, C. L. (1986). Factors in the distribution of intertidal, estuarine polychaetes: a field experiment with Nereis (Hediste) diversicolor and Nephthys hombergii in the Tamar at Plymouth. Estuar. coast. Shelf Sci. 22: 603-618

Engelmoer, M., Blomert, A. M. (1985). Broedbiologie van de kluut langs de friese waddenkust, seizoen 1983. RIJP rapport, Rijksdienst voor de IJsselmeerpolders, Lelystad

Esselink, P., Belkum, J. van, Essink, K. (1989). The effect of organic pollution on local distribution of Nereis diversicolor and Corophium volutator. Neth. J. Sea Res. (in press)

Evans, S. M., Rogers, F. (1978). Organization of tubiculous behaviour in the polychaete Nereis diversicolor $(\mathrm{O} . \mathrm{F}$. Müller). Mar. Behav. Physiol. 5: 273-288

Evans, P. R., Herdson, D. M., Knight, D. J., Pienkowski, M. W. (1979). Short-term effects of reclamation of part of Seal sands, Teesmouth, on wintering waders and shelduck. Oecologia (Berl.) 41: 183-206

Goss-Custard, J. D. (1969). The winter feeding ecology of the redshank, Tringa totanus. Ibis 111.338-356

Goss-Custard, J. D. (1977a). Optimal foraging and the size selection of worms by redshank. Tringa totanus, in the field. Anim. Behav. 25: 10-29

Goss-Custard, J. D. (1977b). The energetics of prey selection by redshank, Tringa totanus (L.), in relation to prey density. J. Anim. Ecol. 46: 1-19

Goerke, H. (1966). Nahrungsfiltiation von Nereis diversicolor O. F. Müller (Nereidae, Polychaeta). Veröff. Inst. Meeresforsch. Bremerh. 10: 49-58

Goerke, H. (1971). Die Ernährungsweise der Nereis-Arten (Polychaeta, Nereidae) der deutschen Küsten. Veröff. Inst. Meeresforsch. Bremerh. 13: 1-50

Green, J. (1968). The biology of estuarine animals. Sidquick \& Jackson, London

Harley, M. B. (1950). Occurrence of a filter feeding mechanism in the polychaete Nereis diversicolor. Nature, Lond. 165: 735

Harley, M. B. (1953). The feeding habits of Nereis diversicolor Br. J. Anim. Behav. 1. 88

Hummel, H. (1985). Food intake of Macoma balthica (Mollusca) in relation to seasonal changes in its potential food on a tidal flat in the Dutch Wadden Sea. Neth. J. Sea Res. 19: $52-76$

Kersten, M., Piersma, T (1984). Voedselkeuze en voedselopname van zilverplevier Pluvialis squatarola in de Waddenzee tijdens voor-en najaarstrek. Limosa 57: 105-111

Kristensen, E. (1981). Direct measurement of ventilation and oxygen uptake in three species of tubiculous polychaetes (Nereis spp.). J comp. Physiol. 145: 45-50

Kristensen, E. (1984). Life cycle, growth and production in estuarine populations of the polychaetes Nereis virens and $N$. diversicolor. Holarct. Ecol. 7: 249-256

Linke, O. (1939). Die Biota des Jadebusenwattes. Helgoländer wiss. Meeresunters. 1. 201-348

Muus, B. J. (1967). The fauna of Danish estuaries and lagoons. Distribution and ecology of dominating species in the shallow reaches of the mesohaline zone. Meddr Danm. Fisk.-og Havunders. 5: 1-316

Newell, R. C. (1979). Biology of intertidal animals. Marine Ecological Surveys, Faversham

Nie, N. H., Hull, C. H., Jenkins, J. G., Steinbrenner, K., Bent, D. H. (1975). SPSS. McGraw-Hill, New York

Pihl, L. (1982). Food intake of young cod and flounder in a shallow bay on the Swedish west coast. Neth. J. Sea Res. 15: 419-432

Pihl, L., Rosenberg, R. (1984). Food selection and consumption of the shrimp Crangon crangon in some shallow marine areas in western Sweden. Mar Ecol. Prog. Ser 15: $159-168$

Ratcliffe, P. J., Jones, N. V., Walters, N. J. (1981). The survival of Macoma balthica (L.) in mobile sediments. In: Jones, N. V., Wolff, W. J. (eds.) Feeding and survival strategies of estuarine organisms. Plenum Press, New York, p. 91-108

Reise, K. (1979). Moderate predation on meiofauna by the macrobenthos of the Wadden Sea. Helgoländer wiss. Meeresunters. 32: 453-465

Ronn, C., Bonsdorf, E., Nelson, W. G. (1988). Predation as a mechanism of interference within infauna in shallow brackish water soft bottoms; experiments with an infauna predator Nereis diversicolor O. F. Müller. J. exp. mar. Biol. Ecol. 116: 143-157

Summers, R. W. (1980). The diet and feeding behaviour of the flounder Platichthys flesus (L.) in the Ythan estuary, Aberdeenshire, Scotland. Estuar. coast. mar Sci. 11: 217-232

Thamdrup, H. M. (1935). Beiträge zur Ökologie der Wattenfauna auf experimentelle Grundlage. Meddr Danm. Fisk.og Havunders. (Ser. Fiskeri) 10: 1-125

Tjallingii, S. T (1969). Habitatkeuze en -gebruik van de kluut. Doctoraalverslag, Zoological Laboratory, University of Groningen, Haren

Twisk, F. (1986). Resultaten onderzoek beschikbaarheid bodemdieren voor vogels. Notitie 86.157 (internal paper), Rijkswaterstaat Tidal Waters Division, Middelburg

Vader, W. J. M. (1964). A preliminary investigation into the reactions of the infauna of the tidal flats to tidal fluctuations in water level. Neth. J. Sea Res. 2: 189-222

Vlas, J. de (1979). Annual food intake by plaice and flounder in a tidal flat area in the Dutch Wadden Sea, with special reference to consumption of regenerating parts of macrobenthic prey. Neth. J. Sea Res. 13: 117-153

Wilde, P. A. W. J. de, Burghuis, E. M. (1979). Cyclic temperature fluctuations in a tidal mud-flat. In: Naylor, E., Hartnoll, R. G. (eds.) Cyclic phenomena in marine plants and animals. Pergamon Press, Oxford, p. 435-441

Witte, F., de Wilde, P. A. W. J. (1979). On the ecological relation between Nereis diversicolor and juvenile Arenicola marina. Neth. J. Sea Res. 13: 394-405

Wolff, W J. (1973). The estuary as a habitat. An analysis of data on the soft-bottom macrofauna of the estuarine area of the rivers Rhine, Meuse and Scheldt. Zool. Verh., Leiden 126: $1-242$

Worrall, D. H. (1984). Diet of the Dunlin Calidris alpina in the Severn estuary. Bird Study 31: 203-212

Zwarts, I. (1986). Burying depth of the benthic bivalve 
Scrobicularia plana (da Costa) in relation to siphon-cropping. J. exp. mar Biol. Ecol. 101: 25-39

Zwarts, L. (1988). De bodemfauna van de Fries-Groningse Waddenkust. Flevobericht 194, Rijksdienst voor de YJsselmeerpolders, Lelystad

Zwarts, L., Esselink, P. (1989). Versatility of male curlews

This article was presented by Professor J. J. Zijlstra, Den Burg, The Netherlands
(Numenius arquata) preying upon Nereis diversicolor: deploying contrasting capture modes dependent on prey availability. Mar. Ecol. Prog. Ser 56: 255-269

Zwarts, L., Wanink, J. (1989). Siphon size and burying depth in deposit- and suspension-feeding benthic bivalves. Mar Biol. 100: 227-240

Manuscript first received: December 8, 1988 Revised version accepted: May 24, 1989 